also state that this species is the "only Empidonax to pump tail down first." 2

This bird may have been a Gray Flycatcher. I could and did see it well. I am equally sure that it had not stowed away in my van, in which, coincidentally, I had just spent some 3 weeks in the mountains and Great Basin of Wyoming and Colorado, much more "home" to Gray Flycatchers than Saskatchewan - where there is no previous record of their occurrence. However, for the moment, this is "the bird that got away."

BAILEY, S.F. 1983 Gray Flycatcher. P. 266 In FARRAND, JOHN JR. 1983 Audubon Society Master Guide to Birding $V$. 2.Knopf, New York

2 ROBBINS, C.S., B. BRUNN and H.S.ZIM 1983 A guide to field identification - birds of North America. Golden Press, New York

\title{
A FURTHER REPORT ON GREAT CRESTED FLYCATCHERS
}

JEAN BANCROFT, 306-200 Tuxedo Avenue, Winnipeg, Manitoba. R3P OR3

For the past five summers a pair of Great Crested Flycatchers has occupied a nest box set up in the wooded area of our summer property at Whytewold on Lake Winnipeg. Apart from the fact that it was enjoyable to have had this particular species close at hand, the main purpose of the research was to make observations, and above all, to ascertain if any different materials had been used for nest building.

The first three years, 1981-83, have already been reported upon. ${ }^{1}$ Further details presented here are for 1984-85.

At the end of May, 1984, the birds appeared as usual and occupied the nest box. Nesting was completed on 17 July; early that morning three fledglings were perched on bare branches near the nest box. There were a great many calls from the young and, on one occasion, a loud whistle came from the male to give warning of two Grey Squirrels which were climbing up and down the nearby trees. At $1900 \mathrm{~h}$ there was a great deal of commotion. The male was darting around the treetops at the front of our property and, after a few moments, six fledglings were located, perched on an oak branch $9 \mathrm{~m}$ from the ground and about $19 \mathrm{~m}$ from the nest site.

After an absence of 12 days, during which calls were heard occasionally from a wooded area about $60 \mathrm{~m}$ distant, the entire family returned to the yard. On 31 July, 14 days after fledging, one young was observed being fed.

On 5 July 1984 I located another nest site about $0.4 \mathrm{~km}$ away. Both male and female were feeding young in a cavity of a hollowed-out log attached to an oak tree, approximately $3.6 \mathrm{~m}$ from the ground. Although it was only $3 \mathrm{~m}$ from a cottage sundeck, and Great Cresteds are usually cautious, secretive birds of the woods, the nest had been built before the owners had opened their cottage. There were many trees on this property.

The birds had a very narrow nesting space; the log was about $32.5 \mathrm{~cm}$ long, and $12.5 \mathrm{~cm}$ wide, with a crack down the centre nearly $1.25 \mathrm{~cm}$ wide. The entrance hole was $7.5 \mathrm{~cm}$ diameter and $6.25 \mathrm{~cm}$ from the top.

On 9 July three young were seen when the adults came with insects; 14 July calls 
came from a nearby wooded area and only one young remained in the nest log. The following day the nest was empty.

In 1985 Great Crested Flycatcher calls were heard at $1115 \mathrm{~h}$ on 30 May. One of a pair looked into our nest box, and then entered it. Although I was not able to tag the birds I felt that it was the same pair that returned to the nest box every year. ${ }^{4}$

Nothing unusual happened until early 7 July when there were many loud raucous calls. Both male and female had been feeding the young for at least 3 days. There was a furious three-bird chase of Crested Flycatchers through the treetops and half way down the lane, which continued for at least an hour. During this time one bird returned to feed the young, then flew off again. It appeared that another male had entered the established territory of the mated pair. I had witnessed a worse fight during the mating season in 1983.2 3 The literature indicates that aerial combat is not unusual in Great Crested Flycatchers. ${ }^{5}$

The pair continued to feed the young, of which there were at least three that fledged. The box was empty 17 July, with the fledglings calling from woods $75 \mathrm{~m}$ away. Adults and young were on a wooded lot near the nest site 23 July. Last calls were heard 31 August.

Examination of the nest materials showed some variation. The nest box in 1984 contained the following: a thin base of moss, grasses, dried weed stalks, plant fibres, with animal hair to bind the material together. Also there were a white feather, a small clump of tangled wool, small bits of brown paper and wax paper, two tiny pieces of American Robin egg shell and, in one corner a pile of feather scales in the small nest cup. The nest in the log contained grassy fibres, droppings, wood chips, two white feathers and a tiny piece of wax paper.
The 1985 nest in the nest box had a base of $3 \mathrm{~cm}$ of mixed peat moss, dead oak leaves and plant fibres, all woven in with fine animal hair, also tiny twigs, two small feathers, green prairie grass gone to seed, and a clump of brown material which was identified as shredded inner bark of a dead aspen.

Although cast-off snakeskin is frequently reported as a nest component it was not the case with any of the six nests I examined. ${ }^{2}$ It appears the Great Crested Flycatchers here used whatever trash material they could find. Shredded Cypress bark was the main component in nests of Great Crested Flycatchers observed by Tom Morrill at Tallahassee, Florida, including those in hanging gourds. One nest in the flue of an abandoned wood stove contained a piece of snakeskin. Morrill also observed that as the female picked up nest material there was "the male following her so closely as she does all the work, yelling as though he's doing it all!" This is similar to local observations.'

The Great Crested Flycatcher was originally a "deep forest bird," ${ }^{\prime 6}$ but in view of forest clearing it is interesting to note that they can be attracted to smaller wooded areas by the erection of nest boxes. In 1984 and 1985 there were three other territories in the neighbourhood, although except for one, the nests were not located. It appeared that the nesting sites were approximately $0.4 \mathrm{~km}$ apart.

I wish to acknowledge the help and encouragement of Herb Copland over the 5- year period.

1 BANCROFT, JEAN. 1981. Great Crested Flycatcher. Blue Jay 39(4):226- 228.

2 BANCROFT, JEAN. 1984. Further observations of Great Crested Flycatcher. Blue Jay 42(2):114-116.

${ }^{3}$ BANCROFT, JEAN. 1984. Great-cresteds survived 2-day, 3-bird chase. Nature Society 
BENT, A.C. 1963. Life histories of North American flycatchers, larks, swallows and their allies. Dover reprint. New York, N.Y. $555 \mathrm{pp}$

${ }^{5}$ FOY, D.j. 1985. Territorial combat. Bird Wat-
6 FOREST SERVICE, U.S. DEPT. OF AGRICULTURE. 1977. Cavity-nesting birds of North American forests. Agriculture Handbook No. 511. 112 pp.

\section{UNUSUAL NESTING SITE FOR THE GREAT HORNED OWL}

RAYMOND A. BELANGER, 412 McGillivray Drive, Weyburn, Saskatchewan. S4H $1 \mathrm{M} 1$ and NICK POSTEY, 536 Bannerman Street, Weyburn, Saskatchewan. S4H 1S9

Though the "hoot" of the Great Horned Owl alerted us of its nocturnal presence, we were not aware of its nesting intention. Most of us believed that these great owls migrated to southerly locations during the winter but returned to nest in our parkland areas to the north. This proved not to be the case in the spring of 1985.

Nick Postey had encountered the Great Horned Owls on the Souris Valley Regional Care Centre grounds in Weyburn as early as 1981. During one experience he discovered a pair of Great Horned Owls occupying a squirrel's nest high on a cottonwood tree. Yet Nick never noted the presence of any young and although he observed them several times in the vicinity, the owls seemed to disappear in February.

In January 1985 a pair of Great Horned Owls was discovered in a stand of evergreen trees on the Souris Valley Regional Care Centre grounds. Their coloration differed as one was pale, the other dark brown. A few days later, the pale owl was located across the Souris River by Ray Belanger and Nick Postey.
This area is characterised by flat grasslands with bush growth dispersed amongst scattered, tall old cottonwood and ash trees. The area, which was isolated from contact with people, had an unusual number of magpie nests.

During an early March evening walk through this magpie nesting area we noticed that a Great Horned Owl had occupied a nest some 20 feet up in an old ash tree. The nest was domed with a side entrance and the owl was distinctly visible through the abundance of dried sticks and twigs. This owl was dark brown. During several further visits this owl was still present in the nest, and often the pale owl was perched in a nearby tree. Later in March a newly- hatched Great Horned Owl chick was observed peering from the nest.

Of special interest to us was the choice of the nest. Great Horned Owls usually use the nests of Red-tailed Hawks, Bald Eagles, Herons or occasionally an old leafy nest of a squirrel.' In Saskatchewan, Swainson's and Red-tailed hawk nests are most commonly used. (Pers. comm. C.S. Houston, via D. Hjertaas). We were of 